\title{
CHANGES OF SOIL PHOSPHORUS FRACTIONS IN PARENT MATERIAL OF A MOLLISOL AT THE EARLY PEDOGENIC STAGE IN NORTHEAST CHINA
}

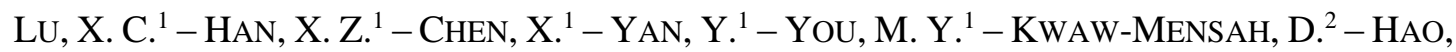 \\ X. X. ${ }^{1}-$ Zou, W. X. ${ }^{*}$
}

${ }^{1}$ Key Laboratory of Mollisols Agroecology, Northeast Institute of Geography and Agroecology, Chinese Academy of Sciences, Harbin 150081, China

${ }^{2}$ Department of Agronomy, Iowa State University, Ames, Iowa, 50011, USA

*Corresponding author

e-mail: zouwenxiu@iga.ac.cn

(Received $8^{\text {th }}$ Nov 2019; accepted $30^{\text {th }}$ Jan 2020)

\begin{abstract}
Fertility degradation of Mollisols affects world food security. Understanding the degradation mechanisms of Mollisols is essential in order to restore the soils' productivity. A long-term field experiment was conducted to assess soil phosphorus (P) concentrations and fractions in a Mollisol at its early development stage under different cropping systems in Northeast China. Parent material (PM) and mature Mollisol (OM) were used for comparison. Organic P (Po) concentrations under natural fallow (Pnat), alfalfa (Medicago sativa L.) (Palf) and soybean-maize (S-M) rotation without fertilizer application (PCS-F) increased by $68-74 \%$ after 10 years. S-M rotation with mineral fertilizer (PCS + F), organic matter amendment (PCS + F + OM), or crop straw return (PCS + F + BM) increased Po concentrations by 74.1-108 mg kg-1 , which is equivalent to $33 \%$ of total $\mathrm{Po}$ in the $\mathrm{OM}$; and increased $\mathrm{Ca}_{2}-\mathrm{P}, \mathrm{Ca}_{8}-\mathrm{P}, \mathrm{Al}-\mathrm{P}$ and Fe-P concentrations by $0.9-1.3,7.1-8.8,2.1-2.7$ and 1.6-1.7 times, respectively. $67 \%$ of the applied fertilizer $\mathrm{P}$ was transformed to $\mathrm{Pi}$ for the treatments with chemical fertilizer. The results indicate that return of crop residue combined with chemical fertilizers enhances the accumulation of $\mathrm{P}$ in soils at their early development stage, which has important implications for the fertility restoration of a Mollisol in Northeast China and elsewhere in the world.
\end{abstract}

Keywords: soil development, natural fallow, long-term restoration experiment, organic phosphorus, inorganic phosphorus

\section{Introduction}

Phosphorus (P) is one of the essential elements for crop growth and development. Over $80 \%$ of $\mathrm{P}$ absorbed by crops comes from a soil reserve (Fageria et al., 2008) and applied fertilizer $\mathrm{P}$ reverts to less available forms in the soil (Han et al., 2005a, b). Therefore, the fractions and availability of soil $\mathrm{P}$, and the transformation and availability of applied fertilizer $\mathrm{P}$ have received much attention in agronomic research (Milic et al., 2019; Sun et al., 2019). Soil P fractions include inorganic P $\left(\mathrm{Ca}_{2}-\mathrm{P}, \mathrm{Ca}_{8}-\mathrm{P}\right.$, Al-P, Fe-P, O-P, Ca $10-\mathrm{P}$ ) and organic $\mathrm{P}$ (labile organic $\mathrm{P}$, moderately labile organic $\mathrm{P}$, moderately stable organic $\mathrm{P}$ and highly stable organic $\mathrm{P}$ ). Generally, organic $\mathrm{P}$ (Po) accounts for 30-65\% of the total P in soils (Pätzold et al., 2013; Jin et al., 2013), while organic P in Mollisol accounts for 42-69\% of total P (Song et al., 2007), which can be attributed to the relatively high organic matter contents (Hou et al., 2014). Crops directly utilize inorganic $\mathrm{P}$ (Pi) in soil solution (generally orthophosphates), which is in dynamic equilibrium with phosphate minerals and surface adsorbed $\mathrm{P}$ in soil (Xiang et al., 2004). With the advancement of soil development, Po fractions become dominant and $\mathrm{P}$ availability is more closely related to the activity of soil microorganisms (van der 
Bom et al., 2019; Richardson et al., 2011). Generally, plant available P comes from the pools of Fe-P, Al-P, moderately labile organic P (MLOP) and labile organic P (LOP) in acid soil; while from the pools of $\mathrm{Ca}_{2}-\mathrm{P}, \mathrm{Ca}_{8}-\mathrm{P}, \mathrm{LOP}$ and MLOP in alkaline soil ( $\mathrm{Li}$ et al., 2005). Therefore, Po fractions play an important role in $\mathrm{P}$ supply, especially in soils with relatively high organic matter content (Vanden Nest et al., 2016; Nobile et al., 2020).

The development and utilization of a Mollisol in Northeast China underwent both natural virgin stages through the stages of cultivation without fertilizer application, cultivation with organic matter application, and cultivation with the combination of organic matter and inorganic fertilizers. The impacts of different cropping systems and agricultural practices on the content and fractions of $\mathrm{P}$ in Mollisol have been reported (Song et al., 2007). Mollisol was fertile in nature and could sustain P supply under both natural and agricultural production systems. Excessive applications of chemical $\mathrm{P}$ fertilizers increased both available and unavailable P fractions (Song et al., 2007). However, the soils in Northeast China suffered from severe erosion as a result of intensive agricultural practices, which has caused $60 \%$ loss of soil organic matter content (Miao et al., 2019). In some extreme cases, soil erosion has removed the surface layer, with exposed parent material ( $\mathrm{C}$ horizon). It is important to understand $\mathrm{P}$ transformations in soil during the period from parent material to current stage.

The restoration of degraded soil has been undertaken at a large-scale and proven to be successful in terms of above-ground ecosystem properties. However, it still lacks understanding regarding soil development in relation to vegetation changes (Griffiths et al., 2008; Harris, 2009), which could be attributed to the fact that it takes a long time to build a high level of soil fertility under natural conditions (Harrison et al., 2008). Anthropogenic activities can accelerate the pedogenic process as indicated by a significant increase in soil organic matter content with all the treatments including no fertilizer, chemical fertilizer and chemical fertilizer plus organic residue amendments during the first eight years of soil development from parent material (You et al., 2017). The inputs of crop residue and manure changed the distribution of carbon $(C)$ density fraction and humic substances. High organic matter input first caused an increase in labile C pool, followed by stable C fractions (You et al., 2014). Soil microbial activity increased with tillage and organic amendment at the early pedogenic stage of parent material, as evidenced by an increase in soil microbial biomass-C and total PLFAs, as compared to the parent material ( $\mathrm{Li}$ et al., 2014). The soil food web was quickly developed with fertility restoration practices (Li et al., 2016). However, information was limited about $\mathrm{P}$ transformations at the initial stage of soil development from the parent material.

Prior studies have focused on the impact of different vegetation types and agricultural practices on $\mathrm{P}$ fractionation in mature Mollisol, with much less attention being paid to young soils. Lu et al. (2015) reported that fertilizer P applied in Mollisol was transformed to Al-P and Fe-P, with less than $20 \%$ being accumulated as Po. Few reports are available about the effects of cropping systems (or vegetation types) and related agricultural practices on the changes of $\mathrm{P}$ fractions in the initial stages of soil development. Accordingly, a field experiment was established in 2004 to examine soil development from parent material ( $\mathrm{C}$ horizon) of a Mollisol. To simulate the effects of cropping systems and agricultural practices on $\mathrm{P}$ fractions at the early development stage of soil, it was hypothesized that application of exogenous $\mathrm{P}$ including chemical fertilizer $\mathrm{P}$ and $\mathrm{P}$ in organic amendment can enhance the accumulation of $\mathrm{P}$ in parent 
material, which can reach relatively high levels within a short term. The objectives of this study were to: (1) identify $\mathrm{P}$ fractions in parent material and; (2) determine the effect of cropping systems and agricultural practices on $\mathrm{P}$ fraction in the initial stage of soil development.

\section{Materials and methods}

\section{Site description and soil sampling}

The long-term restoration experiment was located in the center of the Mollisol' area in Northeast China at the State Key Experimental Station of Agroecology, Chinese Academy of Sciences, Hailun, Heilongjiang province $\left(47^{\circ} 26^{\prime} \mathrm{N}, 126^{\circ} 38^{\prime} \mathrm{S}\right)$. The Mollisol was derived from the sedimentary material of loamy loess parent material (Xiong et al., 1987). Typical soil profiles consist of A-AB-BC-C horizons (A, 0-60 cm; $\mathrm{AB}, 60-115 \mathrm{~cm} ; \mathrm{BC}, 115-150 \mathrm{~cm} ; \mathrm{C},>170 \mathrm{~cm}$ depth). The depth to bedrock is $>20 \mathrm{~m}$. Soil classification is Pachic Haploborolls (fine-silty, mixed, superactive, mesic Pachic Ultic Haploxeroll) according to the USDA Soil Taxonomy (Soil Survey Staff, 2014). The climate in the region is typical temperate continental monsoon, characterized by cold winters and hot summer; with the mean annual temperature of $2.2^{\circ} \mathrm{C}$. The average total annual precipitation is $550 \mathrm{~mm}$, with approximately $358 \mathrm{~mm}$ occurring from June to August.

The long-term restoration experiment started in June 2004 with 24 enclosed plots (each plot measured $1.4 \mathrm{~m}$ long, $1.0 \mathrm{~m}$ wide and $0.8 \mathrm{~m}$ deep). The enclosures consisted of cement strips $(0.2 \mathrm{~m}$ wide and $0.8 \mathrm{~m}$ deep) that protruded $0.1 \mathrm{~m}$ above the ground. These enclosures were refilled with parent material taken from the $2 \mathrm{~m}$ depth (C horizon) below surface near the experimental station. The parent material had a semi-blocky structure. Nylon mesh with $75 \mu \mathrm{m}$ openings was placed on the parent material at $0.8 \mathrm{~m}$ depth to prevent root penetration, but it allowed water and nutrient exchange. The parent material contained $4.79 \mathrm{~g} \mathrm{C}$ and $0.41 \mathrm{~g} \mathrm{~N} \mathrm{~kg}^{-1}$ soil, had a $\mathrm{pH}$ of 6.88 (soil: DI water 1:2.5), bulk density of $1.35 \mathrm{~g} \mathrm{~cm}^{-3}, 420 \mathrm{~g} \mathrm{~kg}^{-1}$ clay $(<0.002 \mathrm{~mm})$ and $356 \mathrm{~g} \mathrm{~kg}^{-1}$ silt $(0.02-0.002 \mathrm{~mm})$. The dominant clay minerals were vermiculite, chlorite and illite (Fig. 1).

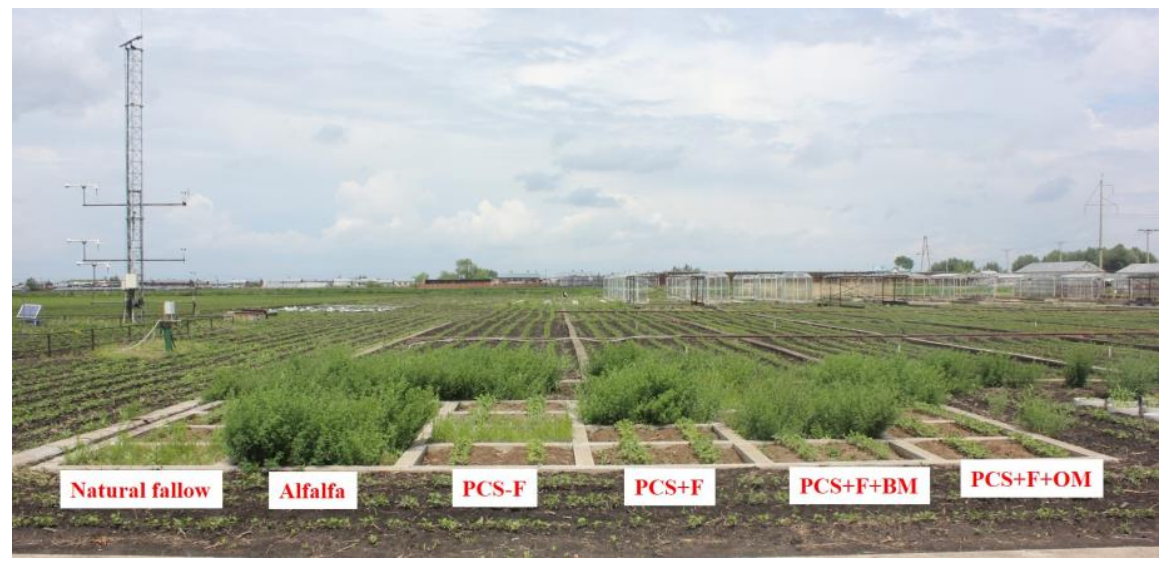

Figure 1. The experimental plots in the field

The following six treatments were assigned to the 24 plots with the parent materials as a randomized block design with four replications: natural fallow without weed 
control (vegetation consisted mainly of Leymus chinensi, Poa annua L. and Equisetum tataricus) (Pnat), N-fixing alfalfa (Medicago sativa L.) (Palf) and four Soybean (S)Maize (M) rotation: (i) S-M without mineral fertilizer and biomass removed (PCS-F), (ii) S-M with mineral fertilizer and biomass removed (PCS + F), (ii) S-M with mineral fertilizer and partial return of residue as a soybean powder-maize straw mixture $(\mathrm{PCS}+\mathrm{F}+\mathrm{OM})$ and (iv) $\mathrm{S}-\mathrm{M}$ with mineral fertilizer and all biomass incorporated (PCS $+\mathrm{F}+\mathrm{BM})($ Table 1 and 2). The biomass in each plot of Pnat and Palf treatments was left in the fields as mulch. In P $+\mathrm{F}-\mathrm{OM}, 2250 \mathrm{~kg} \mathrm{ha}^{-1}$ ground soybean seeds that had been baked at $200{ }^{\circ} \mathrm{C}$ and $4500 \mathrm{~kg} \mathrm{ha}^{-1}$ chopped (20-50 mm long pieces) maize straw were incorporated into the soil at the same time as the other residue return treatments. The $\mathrm{C}$ content in the soybean powder and maize straw was equivalent to the $\mathrm{C}$ content of a typical organic manure application and return of maize straw $\mathrm{C}$ in this region (Qiao et al., 2014). In the PCS + F + BM treatment, the biomass of each year's crop was incorporated into the field, but the maize grain and soybeans were pulverized as above. The fertilizer sources were diammonium phosphate and potassium sulphate, applied at 54,60, and $54 \mathrm{~kg} \mathrm{~N}, \mathrm{P}$ and $\mathrm{K} \mathrm{ha}^{-1}$ year $^{-1}$, respectively, for soybean and maize. An additional $140 \mathrm{~kg} \mathrm{~N} \mathrm{ha}^{-1}$ year $^{-1}$ was applied as urea at the V8 stage of maize growth. The parent material was tilled to $20 \mathrm{~cm}$ depth with a spade to incorporate the chopped crop residue, and ridges $(70 \mathrm{~cm}$ wide and $25 \mathrm{~cm}$ high) were made after applying the organic amendments. The first crop of rotation was soybean. The crop densities were 70000 and 270000 plants $\mathrm{ha}^{-1}$ for maize and soybean, respectively. The varieties of soybean and maize were Dongsheng 7 and Haiyu 6, respectively. The crops were sown in rows in May and harvested in October. At harvest, the above-ground biomass in each plot was cut and weighed, and subsamples were oven-dried at $60{ }^{\circ} \mathrm{C}$ to determine the dry weight of grain and non-grain biomass.

Table 1. The list of abbreviations for field treatments

\begin{tabular}{c|c|c|c|c|c|c}
\hline $\begin{array}{c}\text { Field } \\
\text { treatments }\end{array}$ & $\begin{array}{c}\text { Natural } \\
\text { fallow }\end{array}$ & Alfalfa & $\begin{array}{c}\text { Parent } \\
\text { material }\end{array}$ & $\begin{array}{c}\text { Mineral } \\
\text { fertilizer }\end{array}$ & Biomass & $\begin{array}{c}\text { The mixture of soybean } \\
\text { powder-maize straw }\end{array}$ \\
\hline Abbreviations & Pnat & Palf & PCS & F & BM & OM \\
\hline
\end{tabular}

Table 2. Experimental treatments (i.e. crop rotations, inputs of plant material and mineral fertilizer, tillage) in the 10 years field experiments

\begin{tabular}{c|c|c|c|c}
\hline $\begin{array}{c}\text { Field } \\
\text { treatments }\end{array}$ & $\begin{array}{c}\text { Cropping } \\
\text { systems }^{\mathbf{a}}\end{array}$ & Organic incorporation & $\begin{array}{c}\text { Mineral } \\
\text { fertilizer input }^{\mathbf{b}}\end{array}$ & Tillage $^{\mathbf{d}}$ \\
\hline Pnat & Natural fallow & Litter and roots & None & No \\
Palf & Alfalfa & Litter and roots & None & No \\
PCS-F & Crop rotation & Roots & None & Yes \\
PCS + F & Crop rotation & Roots & Yes \\
PCS + F + BM & Crop rotation & All crop straw, seeds and roots & NPK & Yes \\
PCS + F + OM & Crop rotation & Roots, and amended soybean seeds and maize straw & NPK & Yes \\
\hline
\end{tabular}

${ }^{\mathrm{a}} \mathrm{Crop}$ rotation is the rotation of soybean and maize in different years since 2004

${ }^{b}$ The amendment rates in PCS + F + OM were $2250 \mathrm{~kg} \mathrm{hm}^{-1}$ of baked soybean powder and $4500 \mathrm{~kg} \mathrm{hm}^{-1}$ of maize straw mixed homogeneously. The C:N ratios were 7.4:1 in soybean seeds, 33.5 in maize, 63.3:1 in maize straw and 59.1 in soybean straw

'Diammonium phosphate was source of $\mathrm{N}$ and $\mathrm{P}$ and applied at a rate of $300 \mathrm{~kg} \mathrm{hm}^{-1} \mathrm{yr}^{-1}$; Potassium sulfate (K) was applied at a rate of $120 \mathrm{~kg} \mathrm{hm}^{-1} \mathrm{yr}^{-}$

${ }^{\mathrm{d}}$ Tillage was performed manually down to $20 \mathrm{~cm}$ with ridges made in October after harvest 
Soil samples at the surface layer $(0-20 \mathrm{~cm})$ were collected from the six treatments in all four replications after harvest in October 2013. Composite soil samples, consisting of four random subsamples, were removed with a spade from the ridge and furrow locations and mixed thoroughly. The soil surface layer $(0-20 \mathrm{~cm})$ of each treatment was air-dried after removing all visible roots and plant fragments and sieved through a $2 \mathrm{~mm}$ or $0.25 \mathrm{~mm}$ sieve. The samples of parent material (PM) were taken below $2 \mathrm{~m}$ depth in 2004. Mature Mollisol (OM) was sampled from the A horizon $(0-20 \mathrm{~cm})$ from an adjacent experimental field, which had been cropped to a maize and soybean rotation since 1993 and received only mineral $\mathrm{N}\left(120 \mathrm{~g} \mathrm{~kg}^{-1}\right.$, urea) and $\mathrm{P}\left(51.8 \mathrm{~g} \mathrm{~kg}^{-1}\right.$, diammonium phosphate) fertilizers for maize and $\mathrm{N}\left(20.3 \mathrm{~g} \mathrm{~kg}^{-1}\right.$, urea) and $\mathrm{P}\left(51.8 \mathrm{~g} \mathrm{~kg}^{-}\right.$ ${ }^{1}$ diammonium phosphate) fertilizers for soybean. All aboveground biomass had been removed from field of the mature Mollisol and soil tillage had been manually conducted to the $20 \mathrm{~cm}$ depth using a spade.

\section{Soil sample analysis}

The soil samples were air-dried and sieved through a 2-mm sieve for the laboratory experiment. Total $\mathrm{P}$ (T-P) in soil samples was determined by digesting soil in a tri-acid mixture $\left(\mathrm{HNO}_{3}, \mathrm{HClO}_{4}\right.$, and $\mathrm{H}_{2} \mathrm{SO}_{4}$ at a 3:1:1 ratio) and $\mathrm{P}$ concentration in the digested samples determined calorimetrically using the vanado-molybdate-yellow color method (Jackson, 1973). Soil total organic P was determined after the soil was combusted at $550{ }^{\circ} \mathrm{C}$ and extracted with $4 \mathrm{M} \mathrm{H}_{2} \mathrm{SO}_{4}$ (Anderson, 1960). Available $\mathrm{P}$ was analyzed with the colorimetric molybdenum method following extraction with $0.5 \mathrm{M} \mathrm{NaHCO}_{3}$ (Olsen et al., 1957).

\section{Organic P fractions}

Soil organic $\mathrm{P}(\mathrm{Po})$ was separated into four fractions using a modified sequential extraction procedure developed by Bowman et al. (1978) and modified by Fan et al. (1990). A flow diagram for the Po fraction procedure is given in Figure 2. Highly stable organic P (HSOP) was determined by subtracting the moderately stable organic $\mathrm{P}$ (MSOP) from the stable organic P.

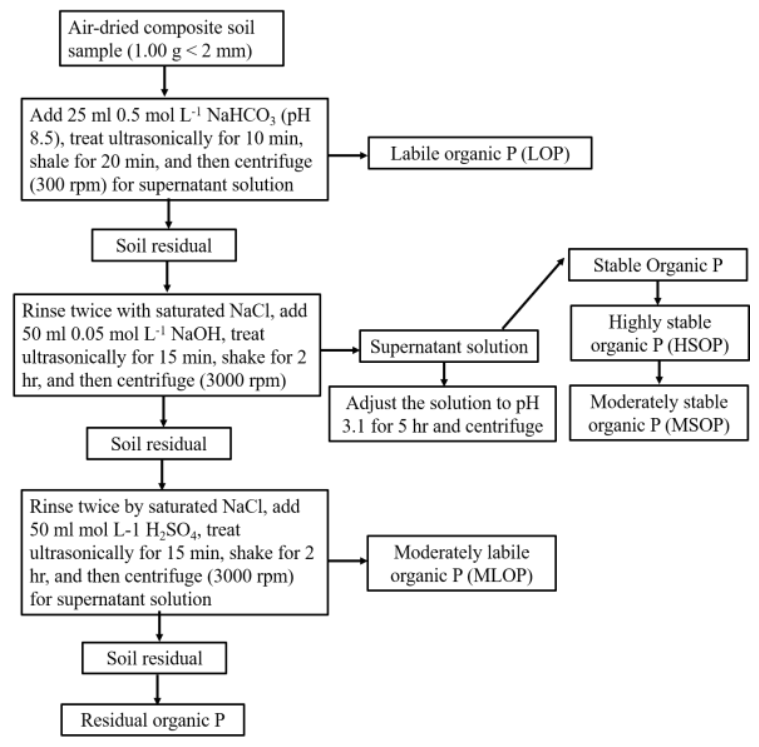

Figure 2. Scheme of sequential extraction of organic P in a Mollisol (Yang et al., 2006) 


\section{Inorganic P fractions}

Inorganic $\mathrm{P}$ fractions were measured according to the fractionation scheme of Jiang et al. (1989) modified from the method described by Chang et al. (1957) and Hedley et al. (1982). Briefly, the fractionation involved a sequential extraction with (1) $0.25 \mathrm{M}$ $\mathrm{NaHCO}_{3}\left(\mathrm{pH} 7.5\right.$ ) to extract $\mathrm{Ca}_{2}-\mathrm{P}$, (2) $0.5 \mathrm{M} \mathrm{CH}_{3} \mathrm{COONH}_{4}$ (pH 4.2) to extract $\mathrm{Ca}_{8}-\mathrm{P}$, (3) $0.5 \mathrm{M} \mathrm{NH}_{4} \mathrm{~F}$ (pH 8.2) to remove Al-P, (4) $0.1 \mathrm{M} \mathrm{NaOH}-0.1 \mathrm{M} \mathrm{Na}_{2} \mathrm{CO}_{3}$ to obtain Fe$\mathrm{P}$, (5) $0.3 \mathrm{M}$ sodium citrate- $\mathrm{Na}_{2} \mathrm{~S}_{2} \mathrm{O}_{4}-0.5 \mathrm{M} \mathrm{NaOH}$ to obtain the occluded $\mathrm{P}$ and (6) $0.5 \mathrm{M} \mathrm{H}_{2} \mathrm{SO}_{4}$ to extract $\mathrm{Ca}_{10}-\mathrm{P}$. These fractions were designated as $\mathrm{NaHCO}_{3}$-soluble $\mathrm{P}$ $\left(\mathrm{Ca}_{2}-\mathrm{P}\right), \mathrm{NH}_{4} \mathrm{Ac}$-soluble $\mathrm{P}(\mathrm{Ca}-\mathrm{P}), \mathrm{NH}_{4} \mathrm{~F}$-soluble $\mathrm{P}(\mathrm{Al}-\mathrm{P}), \mathrm{NaOH}-\mathrm{NaCO}_{3}$-soluble $\mathrm{P}$ (Fe-P), occluded $\mathrm{P}(\mathrm{O}-\mathrm{P})$, and $\mathrm{H}_{2} \mathrm{SO} 4-$ soluble $\mathrm{P}\left(\mathrm{Ca}_{10}-\mathrm{P}\right)$.

\section{Statistical analysis}

The analysis of variance (ANOVA) was performed using the SPSS (version 16, IBM SPSS Statistics, Somer, NY) to determine the significant difference between the treatments. Standard errors were calculated for mean values of determinations. The multiple comparison test was performed using Fisher's (protected) Least Significant Difference (LSD) at the 0.05 significant level. A principal component analysis (PCA) of the soil phosphorus fractions for all the field treatments, mature Mollisol and parent material was generated using CANOCO 5.0 software (written by Cajo J. F. ter Braak and Peter Smilauer, http://www.canoco5.com).

\section{Results}

\section{Total P and Olsen P}

Compared to parent material (PM), total $\mathrm{P}$ in unfertilized soils (Pnat, Palf and PCF-F) did not significantly increase $(P>0.05)$, but Olsen $\mathrm{P}$ did $(P<0.05)$ (Fig. 3). For the treatments with mineral fertilizers and organic matter amendment $(\mathrm{PCS}+\mathrm{F}, \mathrm{PCS}+\mathrm{F}+\mathrm{OM}$ and $\mathrm{PCS}+\mathrm{F}+\mathrm{BM}$ ), total $\mathrm{P}$ concentrations increased by $282.1-330.6 \mathrm{mg} \mathrm{kg}^{-1}$ (Fig. 3), which was equivalent to the total $\mathrm{P}$ concentration in the OM. Olsen $\mathrm{P}$ concentrations increased by 93.3-114.9 mg kg-1 (Fig. 3), which was higher than that in the OM, indicating that application of chemical fertilizers and organic amendment enhanced $\mathrm{P}$ accumulation in soil after the initial10 years of treatments from parent material.
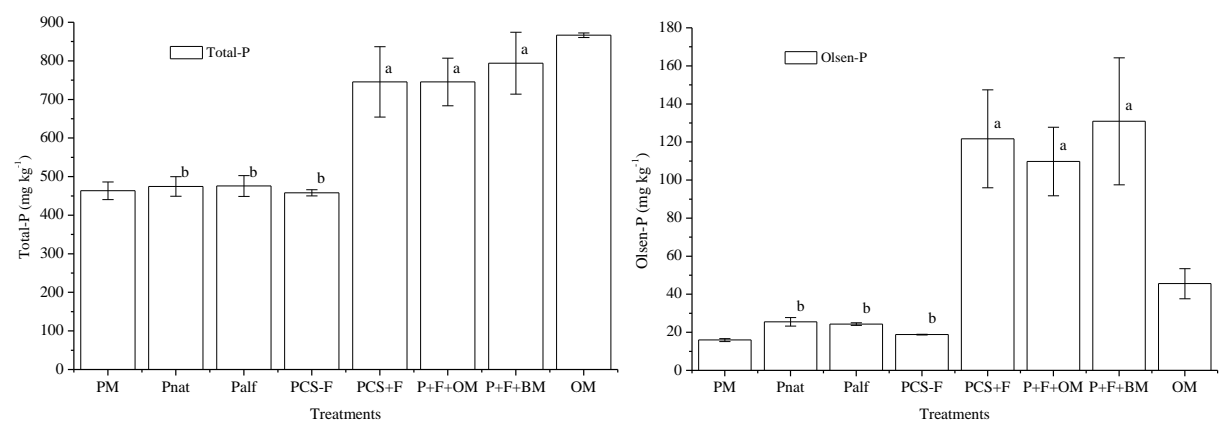

Figure 3. The contents of total $P$ and Olsen $P$ in parent material of soil formation, parent material and mature Mollisol. (Pnat, natural fallow (grasses); Palf, alfalfa; PCS-F, unfertilized soybean-maize $(S-M)$ control; $P C S+F$, chemical fertilizer $S-M ; P C S+F+O M$, organic amendment plus chemical fertilizer $S-M ; P C S+F+B M$, chemical fertilizer and all crop biomass returned $S-M$. Values followed by different letters differ significantly at $\mathrm{P}<0.05$ ) 


\section{Organic and inorganic $P$}

\section{Total organic and inorganic $P$}

Compared to PM, the treatments without chemical fertilizers (Pnat, Palf and PCS-F) increased organic $\mathrm{P}(\mathrm{Po})$ but decreased inorganic $\mathrm{P}$ (Pi) (Fig. 4). However, the treatments with chemical fertilizers and organic amendment $(\mathrm{PCS}+\mathrm{F}, \mathrm{PCS}+\mathrm{F}+\mathrm{OM}$ and $\mathrm{PCS}+\mathrm{F}+\mathrm{BM}$ ) significantly increased $\mathrm{Pi}$ concentrations with the highest value of $586.8 \mathrm{mg} \mathrm{kg}^{-1}$ occurred to the PCS $+\mathrm{F}$ treatment, which was higher than that in $\mathrm{OM}$ $\left(348.7 \mathrm{mg} \mathrm{kg}^{-1}\right.$ ) (Fig. 4). The Po concentrations in all the field treatments increased by $68.2-138 \%$, as compared to PM, and the highest value $\left(186.2 \mathrm{mg} \mathrm{kg}^{-1}\right)$ was observed in the PCS + BM treatment, which was $39.4 \%$ of Po in the OM. OM had a similar Pi concentration as the PM, but had more Po (Fig. 4). The percentages of Po in the total P were lower in PM than OM, which were 57.4\%, 18.2\% and $20.6-31.9 \%$, respectively for OM, PM and all the tested soil. The percentage of Po in total P within Pnat, Palf and PCS-F treatments was higher than those in the PCS +F, PCS +F+OM and PCS + F + BM treatments (Fig. 4).

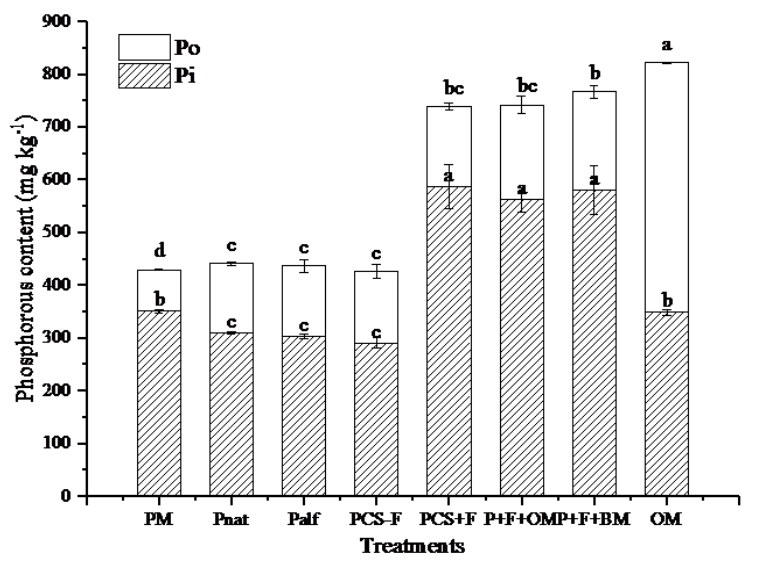

Figure 4. The concentrations of organic $p$ and inorganic $P$ in parent material of soil formation, parent material and mature Mollisol. (Pnat, natural fallow (grasses); Palf, alfalfa; PCS-F, unfertilized soybean-maize ( $S-M)$ control; $P C S+F$, chemical fertilizer $S-M ; P C S+F+O M$, organic amendment plus chemical fertilizer $S-M ; P C S+F+B M$, chemical fertilizer and all crop biomass returned S-M; Po, organic P; Pi, inorganic P; PM, parent material; OM, mature Mollisol. Values followed by different letters differ significantly at $\mathrm{P}<0.05)$

$320 \mathrm{mg} \mathrm{P} \mathrm{kg}{ }^{-1}$ was applied to the soil as diammonium phosphate every year during the 10 years of the experiment in the treatments with chemical fertilizers (PCS + F, $\mathrm{PCS}+\mathrm{F}+\mathrm{OM}$ and $\mathrm{PCS}+\mathrm{F}+\mathrm{BM}$ ) (Table 2). Compared to PM, total $\mathrm{P}$ concentrations in the treatments with chemical fertilizers increased by $282.1-330.6 \mathrm{mg} \mathrm{kg}^{-1}$, which was comparable to the amount of $\mathrm{P}$ applied in fertilizers (Fig. 4). The different total $\mathrm{P}$ concentrations among treatments could be attributed to the removal of $\mathrm{P}$ in aboveground biomass, which possibly caused $\mathrm{P}$ loss in the PCS + F treatment. Total P concentrations in the PCS + BM treatment reached the highest value of $330.6 \mathrm{mg} \mathrm{kg}^{-1}$ (Fig. 3), which is higher than the total $\mathrm{P}$ input via fertilization. This can be attributed to biomass decomposition including aboveground and root biomass (Fig. 3). This indicates that most of the applied P accumulated in the top $0-20 \mathrm{~cm}$ of soil depth. This increased in 
total $\mathrm{P}$ was made up of the increase of $211.1-235.9 \mathrm{mg} \mathrm{kg}^{-1}$ of $\mathrm{Pi}$ and $74.1-108.0 \mathrm{mg} \mathrm{kg}^{-1}$ of Po over the 10-year period of the experiment (Fig. 4). Compared to PM, available P in the $\mathrm{PCS}+\mathrm{F}$, $\mathrm{PCS}+\mathrm{F}+\mathrm{OM}$ and $\mathrm{PCS}+\mathrm{F}+\mathrm{BM}$ treatments increased by 93.8$114.9 \mathrm{mg} \mathrm{kg}^{-1}$, indicating that approximately $33 \%$ of the applied fertilizer $\mathrm{P}$ accumulated in the Olsen P pool (Fig. 4).

\section{Phosphorus fractions}

The total $\mathrm{P}$ concentrations in soil increased after the initial 10 years of experiment regardless of treatments, whilst vegetation types and agricultural practices showed different effects on $\mathrm{Pi}$ fractions (Table 3). There was an increase mainly in the concentrations of LOP and MLOP. Compared with the LOP of PM without P fertilizers, the highest concentration of LOP was found in the PCS + F + OM treatment, which accounted for approximately $25 \%$ of the amount in OM (Table 3). MLOP concentrations in all the tested soils increased by 2.9-5.3 times, with the highest value in the PCS + BM treatment, which was similar to that in OM (Table 3). Treatments with $\mathrm{P}$ fertilization increased MSOP by 15.3-62.2\%, and this accounted for approximately $33 \%$ of the MSOP in the OM (Table 3). The PCS-F and PCS + F treatments decreased the contents of HSOP, but the rest of treatments did not affect HSOP concentrations. The HSOP concentrations in all the tested soil were much lower than that in OM (Table 3).

Table 3. The contents of different $P$ fractions in parent material under treatments, parent material and mature Mollisol

\begin{tabular}{c|c|c|c|c|c|c|c|c|c|c}
\hline \multirow{2}{*}{ Treatments } & \multicolumn{5}{|c|}{ Organic P $\left(\mathbf{m g ~ k g}^{-1}\right)$} & \multicolumn{5}{c}{ Inorganic P $\left(\mathbf{m g ~ k g}^{-1}\right)$} \\
\cline { 2 - 10 } & LOP & MLOP & MSOP & SOP & Ca2-P & Ca8-P & Al-P & Fe-P & O-P & Ca10-P \\
\hline PM & $0.0 \mathrm{e}$ & $19.4 \mathrm{~d}$ & $34.5 \mathrm{~d}$ & $24.3 \mathrm{c}$ & $15.0 \mathrm{c}$ & $4.6 \mathrm{c}$ & $20.4 \mathrm{~b}$ & $94.0 \mathrm{~b}$ & $80.9 \mathrm{ab}$ & $135.9 \mathrm{a}$ \\
Pnat & $0.45 \mathrm{de}$ & $75.0 \mathrm{c}$ & $32.6 \mathrm{~d}$ & $23.4 \mathrm{c}$ & $6.8 \mathrm{~d}$ & $13.4 \mathrm{c}$ & $5.9 \mathrm{c}$ & $114.8 \mathrm{~b}$ & $60.4 \mathrm{bc}$ & $108.2 \mathrm{~b}$ \\
Palf & $0.97 \mathrm{~cd}$ & $79.4 \mathrm{c}$ & $31.3 \mathrm{~d}$ & $21.6 \mathrm{c}$ & $4.4 \mathrm{~d}$ & $8.4 \mathrm{c}$ & $1.4 \mathrm{c}$ & $118.7 \mathrm{~b}$ & $66.2 \mathrm{bc}$ & $109.5 \mathrm{~b}$ \\
PCS-F & $1.68 \mathrm{c}$ & $90.9 \mathrm{bc}$ & $38.5 \mathrm{~cd}$ & $5.1 \mathrm{~d}$ & $3.0 \mathrm{~d}$ & $7.0 \mathrm{c}$ & $5.7 \mathrm{c}$ & $104.8 \mathrm{~b}$ & $65.2 \mathrm{bc}$ & $104.8 \mathrm{~b}$ \\
PCS + F & $0.91 \mathrm{~cd}$ & $98.1 \mathrm{abc}$ & $49.3 \mathrm{bc}$ & $4.0 \mathrm{~d}$ & $32.1 \mathrm{~b}$ & $37.1 \mathrm{a}$ & $76.5 \mathrm{a}$ & $253.8 \mathrm{a}$ & $80.1 \mathrm{ab}$ & $107.2 \mathrm{~b}$ \\
$\mathrm{P}+\mathrm{F}+$ OM & $4.00 \mathrm{~b}$ & $96.3 \mathrm{abc}$ & $56.0 \mathrm{~b}$ & $23.4 \mathrm{c}$ & $28.3 \mathrm{~b}$ & $37.5 \mathrm{a}$ & $63.7 \mathrm{a}$ & $241.4 \mathrm{a}$ & $87.2 \mathrm{a}$ & $103.9 \mathrm{~b}$ \\
$\mathrm{P}+\mathrm{F}+\mathrm{BM}$ & $1.45 \mathrm{c}$ & $116.4 \mathrm{ab}$ & $39.8 \mathrm{~cd}$ & $28.6 \mathrm{~b}$ & $34.3 \mathrm{~b}$ & $45.1 \mathrm{a}$ & $67.9 \mathrm{a}$ & $252.4 \mathrm{a}$ & $77.0 \mathrm{ab}$ & $103.4 \mathrm{~b}$ \\
OM & $16.7 \mathrm{a}$ & $122.1 \mathrm{a}$ & $149.6 \mathrm{a}$ & $184.2 \mathrm{a}$ & $42.2 \mathrm{a}$ & $26.1 \mathrm{~b}$ & $55.7 \mathrm{a}$ & $122.9 \mathrm{~b}$ & $44.2 \mathrm{c}$ & $57.6 \mathrm{c}$ \\
\hline
\end{tabular}

Pnat, natural fallow (grasses); Palf, alfalfa; PCS-F, unfertilized soybean-maize (S-M) control; PCS + F, chemical fertilizer S-M; PCS + F+OM, organic amendment plus chemical fertilizer S-M; $\mathrm{PCS}+\mathrm{F}+\mathrm{BM}$, chemical fertilizer and all crop biomass returned S-M; PM, parent material; OM, mature Mollisol; LOP, labile organic P; MLOP, moderate labile P; MSOP, moderate stable organic P; SOP, stable organic $\mathrm{P}$; $\mathrm{Ca}_{2}-\mathrm{P}, \mathrm{NaHCO}_{3}$-soluble P; $\mathrm{Ca}_{8}-\mathrm{P}, \mathrm{NH}_{4} \mathrm{Ac}$-soluble $\mathrm{P}, \mathrm{Al}-\mathrm{P} \mathrm{NH} \mathrm{NH}_{4} \mathrm{~F}$-soluble P; Fe-P, $\mathrm{NaOH}-\mathrm{NaCO}_{3}$-soluble P; O-P, occluded P; $\mathrm{Ca}_{10}-\mathrm{P}, \mathrm{H}_{2} \mathrm{SO}_{4}$-soluble P. Values followed by different letters at same column differ significantly at $\mathrm{P}<0.05$

In contrast with PM, the treatments without fertilization (Pnat, Palf and PCS-F) decreased the concentrations of $\mathrm{Ca}_{2}-\mathrm{P}, \mathrm{Al}-\mathrm{P}$ and $\mathrm{Ca}_{10}-\mathrm{P}$ and increased the concentrations of $\mathrm{Ca}_{8}-\mathrm{P}$ and $\mathrm{Fe}-\mathrm{P}$, whereas the treatments with fertilization $(\mathrm{PCS}+\mathrm{F}$, $\mathrm{PCS}+\mathrm{F}+\mathrm{OM}$ and $\mathrm{PCS}+\mathrm{F}+\mathrm{BM}$ ) significantly increased the Pi fractions except for $\mathrm{Ca}_{10}-\mathrm{P}$ and $\mathrm{O}-\mathrm{P}$ (Table 3). The concentrations of $\mathrm{Ca}_{2}-\mathrm{P}, \mathrm{Ca}_{8}-\mathrm{P}, \mathrm{Al}-\mathrm{P}$, and $\mathrm{Fe}-\mathrm{P}$ increased by $0.9-1.3,7.1-8.8,2.1-2.7$ and 1.6-1.7 times (Table 3). The concentrations of $\mathrm{Ca}_{2}-\mathrm{P}$, 
$\mathrm{Ca}_{8}-\mathrm{P}$, Al-P, and Fe-P in $\mathrm{OM}$ were much higher than those in $\mathrm{PM}$, but the concentrations of O-P and $\mathrm{Ca}_{10}-\mathrm{P}$ in $\mathrm{OM}$ was lower than those in PM (Table 3).

\section{Pedogenic process of parent material under Mollisol}

Principal component analysis demonstrated that a large difference was found between OM and PM (Fig. 4), parent material with the field treatments had developed into mature Mollisol over the 10-year period of the experiment. Compared with the treatments without fertilizers (Pnat, Palf and PCS-F), the soils receiving fertilized treatments were closer to mature Moillisol (Fig. 5). Inorganic P concentrations in the soils treated with chemical fertilizers $(\mathrm{PCS}+\mathrm{F}+\mathrm{BM}, \mathrm{PCS}+\mathrm{F}+\mathrm{OM}$ and $\mathrm{PCS}+\mathrm{F}$ ) were similar to the $\mathrm{Pi}$ in the $\mathrm{OM}$, but a large difference in Po concentration exists between PM and OM (Fig. 5).

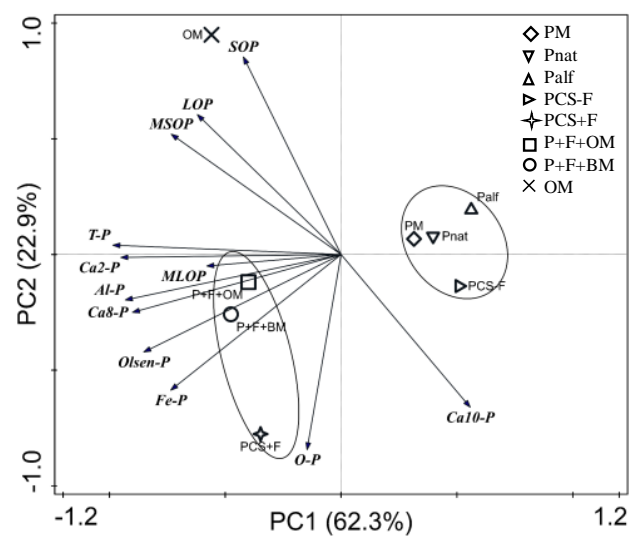

Figure 5. The first two principal components (PC1 and PC2) of soil phosphorus fractions for all the field treatments, mature Mollisol and parent material. (Pnat, natural fallow (grasses); Palf, alfalfa; $P C S-F$, unfertilized soybean-maize $(S-M)$ control; $P C S+F$, chemical fertilizer $S$ $M ; P C S+F+O M$, organic amendment plus chemical fertilizer $S-M ; P C S+F+B M$, chemical fertilizer and all crop biomass returned $S-M$ )

\section{Discussion}

\section{Changes in different $P$ fractions}

Most $\mathrm{P}$ was present as calcium phosphates at the early pedogenic stage of rock, and vegetation occurrence converted Pi to Po in soil ( $\mathrm{Lu}, 1980)$. In the parent material of Mollosil, the Pi concentration was $78.2 \mathrm{mg} \mathrm{kg}^{-1}$, which accounted for $16.55 \%$ of that in mature Mollisol (Fig. 4). The unfertilized treatments (Pnat, Palf and PCS-F) did not increase total P, but increased Po to $131.5-136.1 \mathrm{mg} \mathrm{kg}^{-1}$, accounting for $27.8-28.8 \%$ of Po in OM (Fig. 4), which is consistent with the organic carbon change measured by You et al. (2017), who reported that organic carbon increased by $7-60 \%$ in the same site. Soil organic carbon gradually increased in the parent material after vegetation occurrence, which resulted in an increase in Po, but a decrease in Pi concentration of a similar amount, indicating the transformation of Pi to Po during soil development from parent material. Specifically, $\mathrm{Ca}_{2}-\mathrm{P}, \mathrm{Al}-\mathrm{P}, \mathrm{O}-\mathrm{P}$ and $\mathrm{Ca}_{10}-\mathrm{P}$ were transformed to LOP and MLOP (Table 3), indicating that plants absorbed Pi and returned Po in residues to soil.

The Pnat and Palf treatments demonstrated a similar effect on the transformation of $\mathrm{P}$ fractions, which differed from the PCS-F treatment (Table 3) where SOC was only 
derived from root and litter. This resulted in a relatively low Po concentration with a decrease in HSOP in the PCS-F treatment. Perroni et al. (2014) has documented that Alfalfa growth resulted in an increase in Po in a desert scrub soil in Mexico. Parent material used in the present study had a low SOC $\left(4.8 \mathrm{~g} \mathrm{~kg}^{-1}\right)$ in this study, and the field treatments rapidly increased SOC (You et al., 2017) and subsequently Po in the soil. However, Alfalfa did not show any advantage in the accumulation of Po fractions in the parent material.

A mature Mollisol had been cultivated for hundreds of years, underwent no fertilization stage, farmyard manure stage and chemical fertilization stage. The accumulation of Po increased during soil development and utilization. However, the accumulation of Po concentration became steady at a certain level without the application of inorganic P fertilizers (Song et al., 2011). The transformation of Pi to Po occurred at a lower rate in the treatments without fertilizers where Po accumulation per year accounted for $1 \%$ of that in the mature Mollisol (Table 3). Apparently, external $\mathrm{P}$ inputs could accelerate the accumulation of Po in soil under field conditions.

\section{Effects of fertilizer application on P fractions}

In this study we attempted to accelerate $\mathrm{P}$ formation in the parent material by adding $\mathrm{P}$ fertilizers to contrast with the natural soil development process. $\mathrm{P}$ fertilizer applied to soil was mainly presented as $\mathrm{Pi}$ in the plant-available fractions in parent material under the imposed cropping systems and agricultural practices (Table. 3). The rate of Po accumulation in the treated parent material was relatively slow, but approximately $33 \%$ of the fertilizer $\mathrm{P}$ was transformed to Po. Total $\mathrm{P}$ concentration in the treated parent material was close to that in the mature Mollisol, which may be attributed to the application of P fertilizers over the 10-year of the experiment (Fig. 4). Soil development in the Mollisol parent material was accelerated by $\mathrm{P}$ fertilization based on the result of PCA (Fig. 5), whilst soil development in the vegetation restoration contexts may take hundreds of years to accomplish this level of fertility (Harrison et al., 2008). Po accumulation was as high as $40 \%$ in the mature Mollisol, which is an evidence of the acceleration of soil development in the parent material used in this study.

Reddy et al. (2000) found that soil P fractionation was affected by soil type and fertilization practices, and the application of cattle manure increased the concentration of Po, activated fixed $\mathrm{Pi}$ in soil, and thus enhanced uptake of $\mathrm{P}$ by crops. Application of chemical fertilizers, straw and animal manure increased Pi concentration in the soils of Northwest China (Wei et al., 2011). Chemical fertilizers and organic manure also affected P sorption capacity in a Mollisol (Song et al., 2007). The long-term experiment with a Mollisol showed that chemical fertilizers ( $\mathrm{N}$ and $\mathrm{P}$ ), and the combination of chemical fertilizers with pig manure increased both total $\mathrm{P}$ and Olsen $\mathrm{P}$, dominantly in the forms of $\mathrm{Ca}_{2}-\mathrm{P}, \mathrm{Ca}_{8}-\mathrm{P}$ and Al-P, but no significant increase in Po was noted (Song et al., 2011). Similar results were obtained in present study. P fertilization enhanced Pi accumulation in the treated parent material, which resulted in a significant increase in $\mathrm{Pi}$ with the treatments of PCS + F, PCS + F + OM and PCS + F + BM.

The concentrations of $\mathrm{Pi}$ showed a decreasing order of $\mathrm{PCS}+\mathrm{F}+\mathrm{AM}$, $\mathrm{PCS}+\mathrm{F}+\mathrm{OM}>\mathrm{PCS}+\mathrm{F}>$ Pnat, Palf, PCS-F. The highest value reached $186.2 \mathrm{mg} \mathrm{kg}^{-1}$, accounting for $39.4 \%$ of that in the mature Mollisol (Fig. 4). Accumulated Po in the parent material was mainly derived from crop residues, and a higher rate of organic amendment resulted in more accumulation of Po in soil. 
Long-term field experiments have documented that organic amendment significantly increased the concentration of Olsen $\mathrm{P}$ and reduced soil adsorption capacity for $\mathrm{P}$ (Motavalli et al., 2002; Allen et al., 2006). Low molecular weight organic substances in organic amendment reduced the adsorption capacity of variable charge minerals for $\mathrm{P}$ by competition for adsorbing sites (Guppy et al., 2005). There was no significant difference in the total $\mathrm{P}$ and Olsen $\mathrm{P}$ concentrations between chemical fertilizers alone and the combination of chemical fertilizers and organic amendment. Applied fertilizer $P$ was mainly presented in the Olsen $\mathrm{P}$ pools in the treated parent material. Compared with chemical fertilizer treatment alone (PCS $+\mathrm{F})$, the treatments of chemical fertilizers with organic amendment (PCS $+\mathrm{F}+\mathrm{OM}$ and $\mathrm{PCS}+\mathrm{F}+\mathrm{BM}$ ) had no significant difference in $\mathrm{Pi}$ and $\mathrm{Po}$ concentrations or the $\mathrm{Po}:$ total $\mathrm{P}$ ratio.

\section{Conclusions}

The long-term field experiment was established in 2004 to determine the impact of cropping systems and agricultural practices on soil $\mathrm{P}$ concentration and fractionation during the first 10 years of soil development from parent material of a Mollisol. Po and Pi concentrations were 78.9 and $350.9 \mathrm{mg} \mathrm{kg}^{-1}$ in parent material, and 472.6 and $348.7 \mathrm{mg} \mathrm{kg}^{-1}$ in mature Mollisol. The treatments without chemical fertilizers (Pnat, Palf and PCS-F) enhanced P transformation from Ca2 $-\mathrm{P}, \mathrm{Al}-\mathrm{P}, \mathrm{O}-\mathrm{P}, \mathrm{Ca}_{10}-\mathrm{P}$ to Po in PM. The treatments with chemical fertilizers $(\mathrm{PCS}+\mathrm{F}, \mathrm{PCS}+\mathrm{F}+\mathrm{OM}$ and $\mathrm{PCS}+\mathrm{F}+\mathrm{BM})$ increased total $\mathrm{P}$ concentration in $\mathrm{PM}$ to a level similar to that in $\mathrm{OM}$, Po by 74.1$108 \mathrm{mg} \mathrm{kg}^{-1}$, accounting for 20.6-31.9\% of in the total P, lower than that in the Mollisol. The results from the present study indicate that agricultural practices with fertilizer application can enhance the accumulation of $\mathrm{P}$ during soil development from parent materials of a Mollisol in semi-arid and semi-humid climatic regions in a relatively short period. This information has important implications in the restoration of degraded Mollisols. The further studies are warranted to detect the mechanisms of $\mathrm{P}$ transformation during the process of fertility restoration.

Acknowledgement. The study was supported by the National Basic Research Program of China (No. 2016YFD0300806, 2016YFD0200309 and 2017YFD0300605), the Natural Science Foundation of China (NSFC) (41771327, 41671299 and 41807085), China Agriculture Research System (CARS04), Applied Technology Research and Development Program of Heilongjiang (GY2017ZB006). We are grateful to Zheli He for his modification for the manuscript.

\section{REFERENCES}

[1] Allen, B. L., Mallarino, A. P. (2006): Relationships between extractable soil phosphorus and phosphorus saturation after long-term fertilizer or manure application. - Soil Science Society of America Journal 70: 454-463.

[2] Anderson, G. (1960): Factors affecting the estimation of phosphate-esterin soils. Journal of Food Agriculture \& Environment 11: 497-503.

[3] Bowman, R. A., and Cole, C. V. (1978): An exploratory method for fractionation of organic phosphorus from grassland soils. - Soil Sciences 125: 95-101.

[4] Chang, S. C., Jackson, M. L. (1957): Fractionation of soil labile inorganic phosphorus. Soil Sciences 84: 133-144. 
[5] Fageria, N. K., Baligar, V. C., Li, Y. C. (2008): The role of nutrient efficient plants in improving crop yield in the twenty first century. - Journal of Plant Nutrient 31(6): 11211157.

[6] Fan, Y. K., Xiong, H. D., Li, S. J. (1999): Some improvements of the fractionation method of organic phosphorus in calcareous soils. - Geoderma 193: 195-206.

[7] Griffiths, B. S., Liu, Q., Wang, H. L., Zhang, B., Kuan, H. L., McKenzie, B. M., Hallett, P. D., Daniell, T. J. (2008): Restoration of soil physical and biological stability are not coupled in response to plants and earthworms. - Restoration Ecology 26: 102-104.

[8] Guppy, C. N., Menzies, N. W., Moody, P. W., Blamey, F. P. C. (2005): Competitive sorption reactions between phosphorus and organic matter on soil: a review. - Australian Journal of Soil Research 43: 189-202.

[9] Han, X. Z., Song, C. Y., Wang, S. Y., Tang, C. (2005a): Impact of long-term fertilization on phosphorus status in black soil. - Pedosphere 319-326.

[10] Han, X. Z., Song, C. Y., Wang, S. Y., Qiao, Y. F. (2005b): Phosphorus characteristics correlate with soil fertility of albic luisols. - Plant and Soil 270: 47-56.

[11] Harris, J. (2009): Soil microbial communities and restoration ecology: facilitators or followers? - Science 325: 573-574.

[12] Harrison, R. B., Strahm, B. (2008): Soil Formation. - In: Jørgensen, S. E., Fath, B. D. (eds.) Encyclopedia of Ecology. Elsevier, Amsterdam, pp. 3291-3295.

[13] Hedley, M. J., Stewart, J. W. B., Chauhan, B. S. (1982): Changes in inorganic and organic soil phosphorus fractions induced by cultivation practices and by laboratory incubations. - Soil Science Society of America Journal 46: 970-976.

[14] Hou, E. Q., Chen, C. R., Wen, D. Z., Liu, X. (2014): Relationships of phosphorus fractions to organic carbon content in surface soils in mature subtropical forests, Dinghushan, China. - Soil Research 52: 55-63.

[15] Jackson, M. L. (1973): Soil Chemical Analysis. - Prentice Hall, New Delhi.

[16] Jiang, B. F., Gu, Y. C. (1989): A suggested fraction scheme of inorganic phosphorus in calcareous soils. - Scientia Agricultura Sinica 22: 58-66.

[17] Jin, X. D., He, Y. L., Kirumba, G., Haunas, Y., Li, J. B. (2013): Phosphorus fractions and phosphate sorption-release characteristics of the sediment in the Yangtze River estuary reservoir. - Ecology Engineer 55: 62-66.

[18] Li, L., Li, X. H., Li, X. Y., Li, Y. T., Zhao, B. Q. (2005): Effect of long term fertilization on accumulation, transformation and availability of phosphorous in Fluva-aquic soil. Soil Fertility 3: 32-35.

[19] Li, N., Yao, S. H., You, M. Y., Zhang, Y. L., Qiao, Y. F., Zou, W. X., Han, X. Z., Zhang, B. (2014): Contrasting development of soil microbial community structure under no-tilled perennials and tilled cropping at the initial formation stage of a Mollisol from parent material. - Soil Biology Biochemistry 77: 221-232.

[20] Li, N., Pan, F. J., Han, X. Z., Zhang, B. (2016): Development of soil food web of microbes and nematodes under different agricultural practices during the early stage of pedogenesis of a Mollisol. - Soil Biology Biochemistry 98: 208-216.

[21] Lu, X. C., Zou, W. X., Han, X. Z., Hao, X. X., Jiang, H. (2015): Effect of long term fertilization on phosphorous and zinc fractions in a Mollisol. - Journal of Plant Nutrition and Fertilizers 21(6): 1536-1542.

[22] Miao, S. J., Qiao, Y. F., Yin, Y. F., Jin, J., Martin, B., Liu, X. B., Tang, C. X. (2019): Ten-year application of cattle manure contributes to the build-up of soil organic matter in eroded Mollisols. - Journal of Soils and Sediments 19(7): 3035-3043.

[23] Milic, S., Ninkov, J., Zeremski, T., Latković, D., Šeremešić, S., Radovanović, V., Žarković, B. (2019): Soil fertility and phosphorus fractions in a calcareous chernozem after a long-term field experiment. - Geoderma 339: 9-19.

[24] Motavalli, P. P., Miles, R. J. (2002): Soil fractions after 111 years of animal manure and fertilizer application. - Biology and Fertility of Soils 36: 35-42. 
[25] Nobile, C. M., Bravin, M. N., Becquer, T., Pailat, J. M. (2020): Phosphorus sorption and availability in an andosol after a decade of organic or mineral fertilizer applications: Importance of $\mathrm{pH}$ and organic carbon modifications in soil as compared to phosphorus accumulation. - Chemosphere 239: 1-10.

[26] Olsen, S. R., Cole, C., Watanabe, F. C., Dean, L. A. (1954): Estimation of Available Phosphorus in Soils by Extraction with Sodium Bicarbonate. - USDA Cir. 939. USDA, Washington, DC.

[27] Pätzold, S., Hejcman, M., Barej, J., Schellberg, J. (2013): Soil phosphorus fractions after seven decades of fertilizer application in the Rengen Grassland Experiment. - Journal of Plant Nutrition and Soil Science 176: 910-920.

[28] Perroni, Y., García-Oliva, F., Tapia-Torres, Y., Souza, V. (2014): Relationship between soil $\mathrm{P}$ fractions and microbial biomass in an oligotrophic grassland-desert scrub system. Ecology Research 29: 463-472.

[29] Qiao, Y. F., Miao, S. J., Han, X. Z., You, M. Y., Zhu, X., Horwath, W. R. (2014): The effect of fertilizer practices on $\mathrm{N}$ balance and global warming potential of maize-soybeanwheat rotations in Northeastern China. - Field Crops Research 161: 98-106.

[30] Reddy, D. D., Rao, A. S., Rupa, T. R. (2000): Effects of continuous use of cattle manure and fertilizer phosphorus on crop yields and soil organic phosphorus in a Vertisol. Bioresource Technology 75(2): 113-118.

[31] Richardson, A. E., Simpson, R. J. (2011): Soil microorganisms and phosphorus availability. - Plant Physiology 156(3): 989-996.

[32] Soil Survey Staff (2014): Keys to Soil Taxonomy. 12th Ed. - United States Department of Agriculture, Natural Resources Conservation Service, Government Printing Office, Washington, DC.

[33] Song, C., Han, X. Z. (2007): Phosphorous fertility characteristics of black soil under different types of land use. - Chinese Journal of Soil Science 38(5): 928-933.

[34] Song, C., Han, X. Z., Tang, C. (2007): Changes in phosphorus fractions, sorption and release in Udic Mollisols under different ecosystems. - Biology Fertility and Soils 44: 3747.

[35] Song, C., Han, X. Z., Wang, E. L. (2011): Phosphorus budget and organic phosphorus fractions in response to long-term applications of chemical fertilizers and pig manure in a Mollisol. - Soil Research 49: 253-260.

[36] Sun, D. S., Bi, Q. F., Li, K. J., Dai, P. B., Yu, Y., Zhou. W. W., lv, T., Liu, X. P., Zhu, J., Zhang, Q. C., Jin, C. W., Lu, L. L., Lin, X. Y. (2018): Significance of temperature and water availability for soil phosphorus transformation and microbial community composition as affected by fertilizer sources. - Biology and Fertility of Soils 24: 229-241.

[37] van der Bom, F. J. T., McLaren, T. I., Doolette, A. L., Magid, J., Frossard, E., Oberson, A., Jensen, L. S. (2019): Influence of long-term phosphorus fertilisation history on the availability and chemical nature of soil phosphorus. - Geoderma 355: 1-12.

[38] Vanden Nest, T., Ruysschaert, G., Vandecasteele, B., Houot, S., Baken, S., Smolders, E., Cougnon, M., Reheul, D., Merckx, R. (2016): The long term use of farmyard manure and compost: Effects on P availability, orthophosphate sorption strength and P leaching. Agriculture, Ecosystems \& Environment 216: 23-33.

[39] Wei, X. R., Shao, M. A., Shao, H. B., Gao, J. L., Xu, G. (2011): Fractions and bioavailability of soil inorganic phosphorus in the Loess Plateau of China under different vegetations. - Acta Geological Sinica 85(1): 263-270.

[40] Xiang, W. S., Huang, M., Li, X. Y. (2004): Progress on fractioning of soil phosphorous and availability of various phosphorous fractions to crops in soil. - Journal of Plant Nutrition and Fertilizers 10(6): 663-670.

[41] Xiong, Y. Q., Li, K. (1987): Soils in China. - Science Press, Beijing.

[42] Yang, C. M., Yang, L. Z., Jianhua, L. (2006): Organic phosphorus fractions in organically amended paddy soils in continuously and intermittently flooded conditions. Journal of Environmental Quality 35: 1142-1150. 
[43] You, M. Y., Burger, M., Li, L. J., Zou, W. X., Li, N., Qiao, Y. F. (2014): Changes in soil organic carbon and carbon fractions under different land use and management practices after development from parent material of Mollisols. - Soil Science 179: 205-210.

[44] You, M. Y., Li, N., Zou, W. X., Han, X. Z., Burger, M. (2017): Increase in soil organic carbon in a Mollisol following simulated initial development from parent material. European Journal of Soil Science 68: 39-47. 